\title{
Problems and Exploration of Task-Based Teaching in Primary School English Teaching
}

\author{
Yong Wang a \\ Feixian Campus, Linyi University, Linyi, Shandong, China \\ a fxwangyong@126.com
}

Keywords: Task-based teaching method; Primary school English teaching; Problems; Exploration.

\begin{abstract}
The New English Curriculum Standard highly advocates the use of task-based language teaching, in which teachers should try their best to avoid using traditional teaching method of inputting language knowledge and adopt task-based teaching method to involve students' active participation in the task performance so as to help them learn English through thinking, discussing, communicating and cooperating and others to learn and use English. It follows the principle of "learning by doing", lets students communicate with target language in real context, completes the task of learning goals, constructs target language system in their own experience and forms a comprehensive language using ability. The task-based language teaching method changed the traditional teaching mode, which has its own advantages: students are the center of the class, and the teachers are not the dominators and instructors but participants and guiders to match students in the entire learning process. Students can understand and use language through learning and analyzing to form comprehensive language use ability. Employing TBLT in primary school English teaching can develop students’ integrated language skills.
\end{abstract}

\section{Introduction}

As a world language, English plays a more and more important role in modern society. It is also a language communication tool available on the Internet. In modern society, science and technology developed highly; knowledge update quickly; computer internet makes the way and speed of people's access to information change fundamentally. Only learning English well can people have the ability to direct access to information on the Internet. In short, English will affect people's learning, life and work in a wide range and many English learners will learn English to meet the need of work, life and communication. All these have brought great influence on our country's English teaching and learning. In the state basic education development strategy, English education has become an important part of citizen quality education. English teaching should also be suitable for the demand of social development and change and get rid of the bondage of exam-oriented education.

\section{Characteristics and Advantages of the Task-based Teaching Method}

Task-based teaching method is undoubtedly the embodiment of the advanced teaching idea and method. The characteristics are as follows.

Pay Attention to Language Comprehensive Use in Teaching Goals. Task-based teaching method pursue more than the amount of language activities and the participation of students. In fact, the accuracy of language, the grasp of vocabulary and the use of grammar are also emphasized, which needs to achieve the following objectives. Accuracy: the accuracy of the grammar and language is very important. Comprehensive degree: task-based language teaching emphasizes the integrated use of language. Fluency: the method pays attention to cultivate the students' language fluency.

Advocate Open and Participatory Learning Ways. Let students participate in teaching activities; teachers and students "study together"; students can know more and integrate their knowledge in the process of finding the answer. On teaching skills, task-based teaching believes mechanical activities are required in the early stages, such as the class practicing reading together, drill practice, imitative 
questions-and-answers practice and so on. In the advanced stage they can have mutual interview, problem solving, role plays, discussions, debates, etc.

The Multiplicity of the Teachers' Role. In the implementation of task-based teaching, teachers should adjust their mentality to help students master new knowledge, and at the same time integrate the old and new knowledge into a meaningful system.

Flexibility of Evaluation Methods and Contents. Teachers and students have a common, clear and specific goal. Students know how to work hard to achieve it. Examine students' practical ability of using language, not just memory ability. Combine the learning process and evaluation process. Teachers can evaluate whether students have mastered the knowledge through the students' completing a various of tasks in each days' class. Make the students participate in the activities of evaluation, and the teachers are no longer the only "referees". Give students more freedom of choice in form, content, time and so on to involve them a wider range of knowledge fields and subject content.

The advantages of task-based teaching method are: it can fully mobilize students' learning initiative; create a language use atmosphere in class; set up equal and harmonious relationship between teachers and students; layout the English language and cultural environment on campus. These are the aims of the new curriculum reform and also the need of carrying out quality education.

\section{Task-based Language Teaching Goal}

The Degree of Accuracy. Task-based language teaching method highlights more than the fluency of language. In fact, many advocators put the grammar and accuracy of tone in the first place. Such as Hunan, he explicitly put forward the teaching of the grammar form and should let learners know the purpose of learning to be communicative and how to use these language forms. Say that one of the important reasons of task-based language teaching method gaining recognition from the very beginning by many first-line teachers is that its advocators believe that grammar teaching should not be rejected but be taken seriously. In Second language teaching practice in foreign countries, task-based language teaching method, to some extent, corrected some overpay attention to the language content but neglect the language form.

The Degree of Comprehensiveness. Task-based language teaching method emphasizes the integrated use of language. Some linguists say that the storage of people in their mind when using language is not a single word, not broken language, but pieces of language chalks, and prefabricated phrases and established routines. So, task-based language teaching advocators hold the view that teachers should pay special attention to the following: students can master how many prefabricated phrases and established routines and can use them to realize the communicative purpose to what extent.

The Degree of Fluency. Task-based language teaching method focuses on the cultivation of language accuracy in a variety of ways, such as through group activities and students' autonomous learning to increase language input and output. Through using language to communicate, their language accuracy will be improved. Though there are mistakes when using language, it does not affect communication, because the purpose is to cultivate students' use of language without long pause or hesitation.

\section{The Implementation Steps of Task-based Teaching}

British linguist Jane Wills put forward three steps in his Task-based Framework of Learning: pre-task, task cycle and language focus. Each stage is composed of a number of specific steps.

Pre-task: Introduction of Subjects and Tasks. Task-based classroom teaching should put forward tasks from the very beginning, let the students study language knowledge and do language skills in the drive of tasks. This kind of learning process is task-driving and conducive to improving students' learning interest and strengthening their motivation, as well as reflecting the authenticity of the task. If the teachers' classroom teaching didn't present tasks from the beginning but present and let 
students' finish them after the knowledge learning and skill training, students' learning motivation would become not so strong. But in the present case, most teachers discuss new topic firstly, then introduce new words and phrases, and then assignments.

Task Cycle. Task cycle can be understood as the process of students or groups completing tasks through autonomous and cooperative learning activities, which is an important step to cultivate students' autonomous learning, cooperative learning, creative thinking and practical ability. It consists of three main parts, namely task, presentation and the result of the report task.

Language Focus. The final phase of the Willis model is language focus, also called language analysis. Willis thinks that it is not enough to do tasks only. On the basis of completing the tasks, learners should also learn and drill important language projects consciously. That is to say, learners need to experience a process from meaning to form.

\section{The Requirements of the Mode of Applicative Task-based Teaching to Teachers}

Teachers Should Use Fluent Oral English. Task-based teaching requires students to learn autonomously. Teachers are no longer the embodiment of knowledge, but "communicators" instead of "lecturers", and they should be able to use fluent English to communicate with students naturally. Only in this way can we give clear orders, guide timely and put forward suggestions.

Teachers Should Collocate and Manage the Class. Task-based teaching put forward higher request to the teachers' classroom management. The effectiveness of completing tasks depends largely on teachers' control. For example, Teachers determine the number of people taking part in the task. Although this has been prepared before class but should constantly adjust according to actual situation.

Teachers Should Solve the Problem Timely. There will be all sorts of problems in classroom teaching, and these problems will influence the completion effect of the task. Teacher should solve these kinds of targeted problems.

Teachers Should Make a Timely Evaluation to the Results. One expert said, "Evaluation to teaching, just like spring breeze to the flowers and trees." However, when teachers design activities, they easily tend to ignore the incentive effect of activity results. The results of the task-based teaching activities make students have a sense of accomplishment and pride, so teachers should evaluate the students in a timely manner.

Teachers Should Put their Real Emotion into Class. English, as a communicative language, requires equal communication between teachers and students, mutual cooperation, full embodiment of partnership in each link of teaching, so teachers should adopt more encouragement, equality and tolerance to students rather than imperative or forced ways. And, teachers shouldn't have any bias and always ask top students but ignore the common ones. In addition, teachers must have good teaching behavior and body language.

\section{The Problems that Should be Paid Attention to in the Implementation of Task-based Teaching}

Teachers should Correctly Understand and Grasp the Errors and Mistakes Appeared in the Learning Process. Errors and mistakes are impassable links in the English learning process. "Errors---unconscious errors---consciousness of errors---self-correcting errors", is necessary when learning English. So, teachers shouldn't be afraid of students' making mistakes but listen to students' fragmented English and give them fully understanding. Moreover, language learning lays importance on communication, while communication emphasizes on the understanding of meaning and correctness of information. Teachers should help students know that grammar mistakes occurred in communication don't influence understanding and adopt the strategy of neglecting. People are born in the ability of induction and perfect. Teachers shouldn't worry about mistakes that are not grammatical becoming a habit in communication if teachers insist on the influent correct use of language and guarantee students enough practice. 
Setting Aside Enough Time and Space for Students' Full Performance and Self-development. Enabling students to study and communicate independently is the soul of every English class. Only realizing the autonomous learning can the individualization of study be embodied, and every student get true development. Therefore, we should set aside students enough time and space in class to let them perform fully. The so-called setting aside enough time means that teachers shouldn't occupy most of class time to explain language knowledge; the so-called setting aside enough space means that teachers shouldn't break language points into pieces, so that students have no space of thinking. Teacher should reduce the proportion of explaining. Therefore, teachers must analyze textbooks carefully when preparing the teaching material and find out the space left for students.

The Use of ask-based Teaching should Take Specific Teaching Situation into Consideration. The to help students over the equal periods of time are likely to make greater progress. Therefore, the teachers' how to renew the idea, how to reasonably arrange the teaching progress, and how to correctly deal with the relationship between the ability training and examination results, are worth exploring.

The ultimate goal of English teaching is for communication. Task-based teaching completely solves the fragmentation between the traditional grammar teaching and practical application, between language form and meaning and other abnormal phenomenon in English teaching. Task-based learning process is full of reflection, insight and introspection, thus maximize students' inner motivation, improve students' ability of discovering and solving problems, develop their cognitive strategy, cultivate their spirit of cooperation and participation, experience the joy of success in the process of completing the task, and give full play to their potential. In the task-based teaching, the teachers play roles of language acquisition promoters, solvers and guiders.

Task-based teaching in primary English teaching emphasizes the cultivation of students' language ability, pays attention to the development of students' learning strategies, promotes the improvement of students' innovative spirit and practice ability, fully embodies the concept of quality education of teachers as guiders and students as main bodies, stimulate students' divergent thinking, and let the students creative use of language. Just as the famous expert of task-based learning David Nunan said: the task of interactive learning can stimulate students to mobilize all language resources and make their language knowledge to the vertex.

\section{References}

[1]. Crookes, G V. Task class: A cross-disciplinary review. Technical Report No. 4. Honolulu, Center for Second Language Research, Social Science. Research Institute, University of Hawaii. 1986.

[2]. Nunan D. Second Language Teaching \& Learning. Heinle\&Heinle Publishers. 1999.

[3]. NunanD. Language Teaching Methodology. Prentice Hall. 1991.

[4]. Estaire, S. \& Zanon, J. Planning Glasswork-A task-based approach. Macmillan Publishers Limited. 1998.

[5]. Brown H.D. Teaching Principles: An Interactive Approach to Language Pedagogy. Prentice Hall Regents. 1994.

[6]. Candlin C. \& Mupby D. Language Learning Task. Prentice Hall. 1987.

[7]. Dale Scott Ridley \& Bill Walther, Creating Responsible Learners: The Role of a Positive Classroom Environment. China Light Industry Press. 2001

[8]. Chuai Tiemei. Research and Practice of the Mode of the Task-based English Classroom Teaching. Liaoning Education Research. 2007.6:93-95. 